\title{
The Effect of the (Rothkopf) Model on Developing Conciliatory Thinking among Fourth-Grade Literary Students in History
}

\author{
Murad Ahmed Khalaf ${ }^{a}$ \\ College of Education, University of Samarra, Samarra, Iraq.
}

Article History: Received: 11 January 2021; Accepted: 27 February 2021; Published online: 5 April 2021

\begin{abstract}
After identifying the subjects of the subject to be studied in the course of the experiment by five subjects, and for the purpose of measuring the compromise thinking test for the two sets of subjects studied by the researcher himself, the researcher prepared a compromise thinking test, presented to a group of experts and specialists to verify the truthfulness of the test, to analyze its paragraphs and calculate its persistence, and after analyzing the results of the responses of female sample students and statistically addressing them using appropriate statistical means, he found that the test was all paragraphs of the test.

After the completion of the (11) week-long experiment, the Compromise Thinking Test was applied to the requests of the pilot and officer groups, and after statistical analysis and processing of female students' answers using the T test for two linked samples, a statistically significant difference was found between the average grades of female students in the two research groups. The results also showed that the difference is statistically significant and that this difference in compromise thinking is in favor of the experimental group for the test of remote compromise thinking.
\end{abstract}

\section{Introduction}

\section{Aims of the Study}

The current research aims at identifying the impact of Rothkopf on the development of compromise thinking in literary fourth graders in history.

There is no statistically significant difference at the 05.0 level between the average score of female students of the experimental group studying history in accordance with the Rothkopf model and the average score of female students of the officer group studying the same subject in the traditional method of compromise testing.

\section{1- Definition of research}

Search problem: Almost the most important problem with this research here is that it is an opaque tool for many teachers and professors alike, but in terms of the researcher, it has been able to come up with a lot of valuable information. The problem of the teaching method was originally based on the so-called routine approach, i.e., by throwing by the teacher and by students having to absorb, preserve and not use any educational or technical means. Despite all the efforts made by those working in this area and the qualitative and quantitative changes that have taken place, their programs and activities remain far below the level of ambition to develop sound thinking among students.

Its programs and evaluation methods for students still focus on indoctrinating facts and information, and the learner exercises a passive role in the educational process, adapting to receiving the subject matter specified in the prescribed books and repeating what is thrown at him and accepting it without criticism or research, and this case applies to the various stages of education (Al-Janabi, 1992: 9) Therefore, there is a problem that takes different dimensions in complexity and defines the students in a narrow range of their ability and ways of thinking in ensuring that dealing with what the teachers and teachers request, and they were satisfied with emphasizing what students memorized and absorbed of study materials without training on employing their ability to face problems in correct ways of thinking. With what makes him think about any problem in good scientific thinking, the school must provide the learner with different information in various aspects of science, literature and the arts. Rather, it must give special attention to his learning of new methods and methods of thinking, and the researcher thinks that the students' stumbling in the history course is difficult to understand and acquire This is what has been confirmed by some specialized history teachers and methods of teaching it, as confirmed by some previous studies, including the study of Al-Sudani (2011) and Al-Tamimi study (2012)

Therefore, finding modern models that help students raise their achievement away from the traditional methods such as lecturing, discussion ... etc, which are based on memorization and indoctrination.

\section{2-The importance of research.}

Education takes care of the individual and places him or her at the center of the educational process. The educational system must meet several basic requirements, including the search for mental changes that can affect students' educational achievement. Especially thinking and trying to match these changes can affect the educational achievement of female students. In particular, thinking capabilities and trying to cope with these changes by diversifying experience and knowledge in a manner appropriate to these different capacities. It allows teachers to invest in, develop and nurture all intellectual activities owned by female students as dynamic processes. (Shahata, 2003:103).

History is a basic social material with educational values as a material of general weight and value and with objectives to be pursued and promoted by educators; Because knowledge of a nation's national heritage, its 
civilization, and pride in what grandparents have achieved is a fundamental goal that must be seen and promoted by female students (Abedi, 2006:4).

The study of history also seeks to give female students various skills such as identifying, studying and solving problems, identifying, collecting, organizing and evaluating sources of information, reading, understanding, interpreting and analyzing maps, photographs and historical drawings, and understanding the meaning of time. 1)

Social teaching methods, including history, emphasize that teaching should be done through practical activities carried out by the learner under the guidance of the teacher in both the classroom and the laboratory, as well as the adoption of contemporary teaching modules. One of the components of a successful teacher is the selection of the appropriate educational model. Rothkopf emphasizes the importance of the role of the learner in the study of educational subjects and emphasizes his or her appropriate activities in the classroom, and in order to achieve the educational objectives set out in the educational situation;

Rothkopf has developed three levels of learning-generating activity, namely, preparation, targeting, and translation of material or texts by adopting most of the senses. Mooney, The Ruse, 9200 (184: Rothkopf dealt with several studies, including Rothkopf \& Mary, 1978, which aimed to identify the impact of the organization of the text on the achievement of goals, and found that the pilot group was better than the control group in setting and achieving goals, while this was not achieved in the control group (Rothkopf\&Mary,1978).

Thinking is a cognitive process or a mental act in which knowledge is acquired, and thinking is at the top of the pyramid of activity. By doing so, human beings are able to employ most, if not almost all, of the other mental processes, thinking is directed at all the problems we face to find appropriate alternatives and solutions, and teachers have to focus on scientific thinking skills.

Students are informed of how to perform properly against problems, how to select information related to the problem, and how to detect and coordinate the situation in order to facilitate proper performance. Thinking is a complex concept consisting of three elements of complex knowledge processes, primarily problem solving, Less complex, such as understanding and application, as well as special knowledge of the content of the subject matter, with various personal preparations, particularly trends and tendencies.

(Happiness, 2006:40) Therefore, no society can progress and evolve unless its members have different thinking skills that help them to advance it to keep pace with the age of informatics. Learning to think is therefore one of the most important educational goals that education seeks to achieve in order to create a creative mindset that confronts problems in a positive way. It helps individuals to absorb multiple knowledge and opinions after checking their truthfulness, adopting mind-acceptable opinions and trends, and helping them to distinguish between opinions based on logic and weak opinions. (Mohamed, 2015).

The combinational thinking is an ability used to depart from the norm in the process of thought, response and reaction, or to perceive those processes and their development in a variety of ways. Moreover, combinational thinking helps individuals to find methods and methods that help them in reaching and achieving the goal (Debono, 2010: 48). Combinational thinking is very important because thinking is one of the advantages of not being rigid as it is inevitable because impressions play an important role in improving and deepening an individual's ability to adapt as a mature person. (Abdel-Rahman, 2018)

In the same context, compromise thinking helps to interact and adapt positively to what is before you, as it gives the ability to find different options and diverse solutions and to choose from them a situation or an event that we experience in our lives. Thinking has many patterns that vary according to their representation of the way an individual receives knowledge, experience and information (Idris, 2010: The researcher considers that the importance of developing compromise thinking, problem-solving skills and initiative directions leads to the formation of people who are proactive in learning from a lifelong learning perspective and that individuals develop their skills in information processing, query, evaluation and decision-making.

The importance of the research can be summarized as follows:

- The research seeks to experiment with Rothkopf and, as far as the researcher is aware, there has never been a local study of history for literary fourth grade.

- A Rothkopf model can help female students raise their achievement and improve their compromise thinking

- To keep pace with recent educational trends calling for a positive role for female students in the educational process.

- This study can draw the attention of those responsible for the educational process to the importance of the compromise thinking of history teachers.

- The researcher hopes that this study will serve as a gateway to other educational research and studies in history and other teaching methods.

\section{3- Search Target}

The research aims to identify the impact of Rothkopf in the development of compromise thinking in literary fourth graders in history.

\section{4- Research hypotheses}

There is no statistically significant difference at the 05.0 level between the average score of female students of the experimental group studying history in accordance with the Rothkopf model and the average score of female students of the officer group studying the same subject in the traditional method of compromise testing.

There is no statistically significant difference at the 05.0 level between the average differences in the scores of the tribal and postdoctoral tests of female students of the experimental group studying history at Rothkopf and 
the average differences in the scores of the tribal and postdoctoral tests of female officers studying the same subject according to the traditional method of testing for the development of compromise thinking.

\section{Theoretical framework and previous studies}

Cognitive theory: Cognitive theory is the point of transition from the behavioral aspect and its practices in terms of moving from an emphasis on the external behavior of the learner to an interest in the internal mental processes behind the learner's behavior, as well as how these processes can be used to encourage and stimulate efficient acquisition and learning that has the potential to influence. Changes in the resulting behavior must be used as new indicators in the learner's mind. Knowledge theory addresses knowledge-based processes such as encryption, representation, storage, retrieval, input and integration of information with previous knowledge and information (Obaid, 2009: 83 Cognitive theory assumes that the learner is active, engaging in learning-led experience, searching for information on problem solving, reorganizing and arranging information and experience to collect and capture new information. Instead of being passive, governed by the events of the surrounding environment, the learner chooses, decides, practices, cares, ignores and works out other responses that are vital to achieving the goal (Qatami, 2013: 32).

Jeanne Piaget, as mentioned in Zaghul (2003), clearly and explicitly expressed the blending of psychology, philosophy and biology into his theory; It is a theory of psychology, known as knowledge theory and based on biology, based on three basic axes:

First, knowledge itself is a representative tool that results in the development of knowledge structures.

Second, knowledge performs the function of self-control of a learner's methods of thinking according to the process of mental balance.

Third, cognitive development has two aspects, one quantitative and the other qualitative; In no way can this growth be understood unless these two aspects are addressed, the quantitative aspect of the processes of building knowledge is linked to the world's assets, while the qualitative aspect deals with changes in cognitive structures and mental functions and the knowledge structures can change in the light of ongoing interactions with the environment. Mental functions are unalterable innate components. Studies have therefore focused on knowledge structures and changes. (Algol, 2003: 213).

Based on the foregoing, the researcher considers that education according to cognitive theory is the creation of attitudes in which female students interact with a view to developing their experiences and contributing to the development of thinking strategies and mental processes that they employ in new situations and the reconstruction of knowledge structures. Teaching requires the provision of concrete evidence, practical experience of ideas to be conveyed. Students should be given opportunities to participate in order to achieve good understanding and build information through their own experience. Teaching using Rothkopf can be an expressive model of cognitive theory, with learners actively involved in understanding and representing principles and concepts.

In Rothkopf's view, the teacher's activity is based on the motivating activity of learning.

- Preparation means access to the environment of the educational subject.

- Acquisition of objectives: It is intended to select the target educational material.

- Translation of material or texts, i.e. internal representation using cognitive processes.

Levels I and II can be clearly observed, and levels III of activity (translation of material or texts) is not easily observed, as mental processes take place in the human mind, and is therefore the focus of research within this educational pattern called "learning through written materials." (Gray and the stunt, 184:2009)

(Rothkopf) stresses the importance of the students 'role in studying the educational material or texts on their own, but does not diminish the importance of the texts themselves, in terms of their internal features on the learning process, and (Rothkopf) in this area distinguishes between the nominal or symbolic influences and the effective effects as the influences indicate Symbolism refers to the shape and size of written words, their type and sentences, and the phrases that make up the material or educational texts, and that the educational activities carried out by students transform the nominal effects into effective influences, and thus it can be said that the performance of students is a natural outcome of the nominal influences, i.e. the features or characteristics of texts and processes Mentality he is doing. (Rothkopf) distinguishes three characteristics of the nominal influences belonging to education, after which the nominal influences are available in texts: (content, method of presentation, and form).

The content has the following features:

1- Accuracy in providing facts and information.

2- The orientation related to the educational goal, and its own goals and objectives.

3- Non-affiliated subjects, that is, the extent to which the educational material includes materials unrelated to the goal

Instruction set by the teacher. (Abd al-Hadi, 2004: 115)

Stages of the Rothokopf Model:

1- The stage of determining the desired educational and learning goals

In it, the teacher does the following:

A- Identifying the learners' needs related to the topic.

B- Determining the pre-learning available to the learners, and assessing what the learners need for meaningful and good learning. (Al-Obeidi, 2004: 225)

2- The stage of the availability of the learning environment

A- Selecting appropriate texts to meet the needs of learners. 
B - Organizes texts in a manner that suits the needs of the learners, their abilities and capabilities, and makes sure that the content is appropriate to the needs of students and their prior learning.

3- The stage of enrichment and reinforcement

And in it the teacher does the following:

A. Recasting written texts, enriching them, or enhancing them with additional texts, questions, or training, to enable them to arouse the interest of learners.

B- Availability of educational tools for learning in terms of pictures, shapes, questions, exercises, films and instructions that facilitate the process of learners' interaction with written texts.

4- Evaluation stage

The teacher does the following:

A- Ensure that the learners interact with the available written texts, depending on the available aids, questions and training.

B - Conducting the necessary oral and written tests to ensure access to the desired learning (Meri, Al-Hailah, 1998: 313)

Synthesis thinking: It is considered one of the main and important thinking patterns that the individual practices in his daily life in order to reach a state of balance. The concept of combinational thinking or congruent thinking, or what is sometimes called flexible thinking, agrees with the concept of psychological compatibility, as compatibility is a state of Psychological equilibrium or evidence of an individual's psychological health

The compromise thinking, as defined by specialists and experts: is the ability to adapt, harmony and harmony, and the events of the necessary and necessary balances, internal and external, as well as creating alternatives and options in the way we deal with others, variables and different situations. It is the art of dealing, adapting and adapting to everything that is new and unexpected, and that compromise thinking is the secret of success. Rather, it is one of his keys, whether at work or in social relations, as it represents the ability to face difficult situations with a conscious and soft mind. " (Abdulrahman 2018: 16-17)

(Flexibility) is the cornerstone of the pillars of combinational thinking, which are: a skill of creative thinking skills, which is a cognitive process that leads to the generation of a new product that is characterized by flexibility and originality and is thus not an automatic or random product, but rather the fruit of creative mental efforts that Turner knew Turner - 1994): - that it is an attempt to search for unfamiliar ways to solve a new or old problem. This requires the fluency of thought, its flexibility, originality and the ability to develop solutions to problems, detailing or expanding them. Dealing with serious problems and allows the individual to come to new and unfamiliar ideas as well as allows freedom from the restrictions of society around us and the patterns that limit the ability to creative thinking freely. (Al-Atoum, 2004: 233)

He adds (Abu Riach, 2012) that combinational thinking: is the ability of the individual to justify ideas and choose the validity of strategies for solutions, interaction, cooperation, working in groups and helping to solve a problem with others as well as developing mentally with others and interacting with them.

(Abu Rias, 2012: 1)

The advantages of compromise thinking:

- Compromise-minded individuals are the most capable and influential of others.

- The problem is not solved by the same mindset that I produced earlier.

- Focus and diversity of means in different situations.

- If the desired outcome does not work, the method must be changed directly.

- If everyone cannot see all aspects, they must interact with others and listen to them to avoid their shortcomings.

- The individual must take into account all factors relating to compromise thinking, whether related to the individual or to others. (Successful 2008:15)

Features of compromise thinking:

- A way to protect a person from being broken in difficult situations. In his or her life, man often faces many difficult situations that are never resolved in accordance with his or her wishes or goals.

- Compromise thinking is necessary to achieve goals and achieve success.

- A person with a strong personality has a compromise personality in all circumstances.

- A character of a compromise character cannot be defeated or resisted.

- A character with a flexible compromise is not easily withdrawn and never gives up.

- As Wilmakoutstal's Wilmakoutstaal has emphasized, creativity promotes one's own understanding of compromise, making it able to achieve all objectives, whether personal or collective, effectively and productively.

- The individual is given the ability to adapt and correct calendar. (Tracy, etal, 2011, p106)

Table (1): Previous Studies

\begin{tabular}{|c|c|c|c|c|c|c|c|c|c|c|}
\hline $\begin{array}{c}\text { important } \\
\text { results }\end{array}$ & $\begin{array}{c}\text { Statistical } \\
\text { means }\end{array}$ & $\begin{array}{c}\text { Search } \\
\text { tool }\end{array}$ & 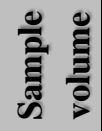 & $\frac{\bar{e}}{\frac{e}{\overline{0}}}$ & $\begin{array}{c}\text { Educational } \\
\text { level }\end{array}$ & Sex & Place & Purpose & year & $\begin{array}{c}\text { researc } \\
\text { her }\end{array}$ \\
\hline
\end{tabular}




\begin{tabular}{|c|c|c|c|c|c|c|c|c|c|c|}
\hline $\begin{array}{c}\text { The } \\
\text { experimental } \\
\text { group that } \\
\text { studied the } \\
\text { Rothkopf } \\
\text { method was } \\
\text { superior to } \\
\text { the control } \\
\text { group that } \\
\text { studied } \\
\text { using the } \\
\text { usual } \\
\text { method in } \\
\text { achievement } \\
\text { and critical } \\
\text {.thinking }\end{array}$ & (T-test) & $\begin{array}{c}\text { Achieve } \\
\text { ment } \\
\text { test } \\
\text { The } \\
\text { critical } \\
\text { thinking } \\
\text { test }\end{array}$ & 52 & 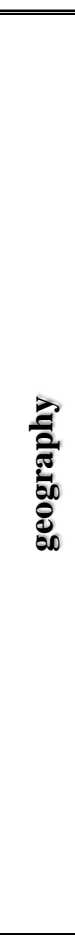 & University & 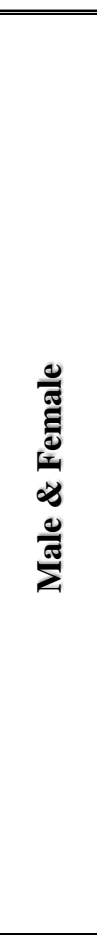 & & 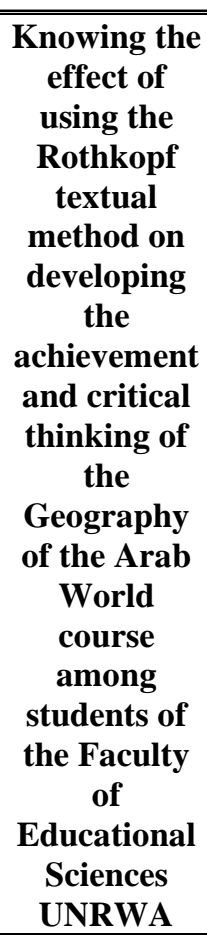 & 2009 & 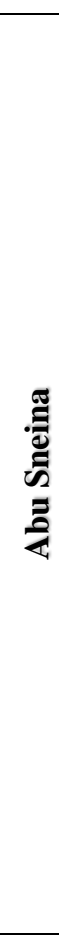 \\
\hline $\begin{array}{c}\text { The } \\
\text { experimental } \\
\text { group that } \\
\text { studied the } \\
\text { Rothkopf } \\
\text { method } \\
\text { outperforme } \\
\text { d the control } \\
\text { group that } \\
\text { studied by } \\
\text { the standard } \\
\text {.method }\end{array}$ & (T-test) & 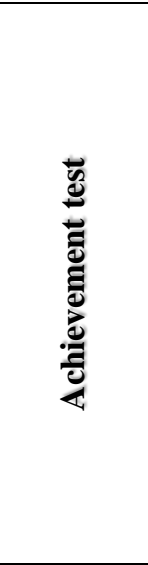 & 70 & 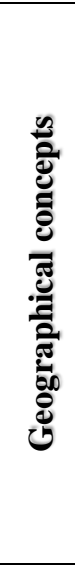 & High School & Male & & $\begin{array}{l}\text { Knowing the } \\
\text { effect of } \\
\text { using the } \\
\text { Rothkopf } \\
\text { model in } \\
\text { teaching } \\
\text { geographical } \\
\text { concepts to } \\
\text { tenth grade } \\
\text { students and } \\
\text { the extent to } \\
\text { which they } \\
\text { retain the } \\
\text { concepts }\end{array}$ & 2010 & 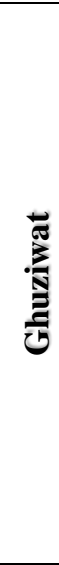 \\
\hline $\begin{array}{c}\text { The } \\
\text { experimental } \\
\text { group that } \\
\text { studied the } \\
\text { Rothkopf } \\
\text { method } \\
\text { outperforme } \\
\text { d the control } \\
\text { group that } \\
\text { studied using } \\
\text { the standard } \\
\text { method of } \\
\text { achievement } \\
\text { and moral } \\
\text { intelligence } \\
\text {.scale }\end{array}$ & (T-test) & $\begin{array}{c}\text { Achieve } \\
\text { ment } \\
\text { test } \\
\text { Moral } \\
\text { Intellige } \\
\text { nce } \\
\text { Scale }\end{array}$ & 42 & 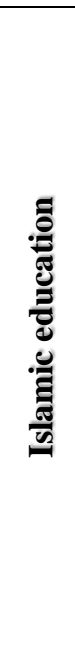 & High School & Male & $\bar{\Xi}$ & $\begin{array}{c}\text { Knowing the } \\
\text { effect of } \\
\text { using the } \\
\text { Rothkopf } \\
\text { method on } \\
\text { developing } \\
\text { moral } \\
\text { intelligence } \\
\text { among fifth- } \\
\text { grade } \\
\text { literary } \\
\text { students in } \\
\text { the subject } \\
\text { of Islamic } \\
\text { education }\end{array}$ & 2011 & 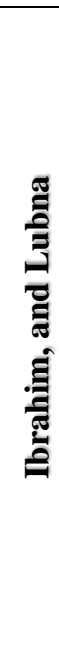 \\
\hline
\end{tabular}




\begin{tabular}{|c|c|c|c|c|c|c|c|c|c|c|}
\hline $\begin{array}{c}\text { The research } \\
\text { sample } \\
\text { possesses } \\
\text { conciliatory } \\
\text { thinking, in } \\
\text { general, } \\
\text { higher than } \\
\text { the average } \\
\text { of the } \\
\text { community } \\
\text { to which } \\
\text { they belong } \\
\text { when } \\
\text { comparing } \\
\text { the achieved } \\
\text { average with } \\
\text { the } \\
\text { hypothetical } \\
\text { sample mean } \\
\end{array}$ & (T-test) & $\begin{array}{c}\text { A } \\
\text { measure } \\
\text { of } \\
\text { personal } \\
\text { ity }\end{array}$ & 400 & $\begin{array}{c}\text { A } \\
\text { measure } \\
\text { of } \\
\text { personal } \\
\text { ity }\end{array}$ & University & 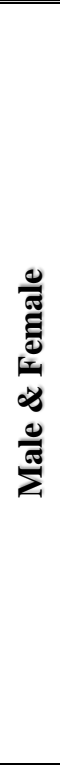 & $\bar{E}$ & $\begin{array}{l}\text { Identify the } \\
\text { level of } \\
\text { reconciliator } \\
y \text { thinking } \\
\text { and its } \\
\text { relationship } \\
\text { to the } \\
\text { influential } \\
\text { personality } \\
\text { of university } \\
\text { students }\end{array}$ & 2018 & $\begin{array}{l}\text { Abdulr } \\
\text { ahman }\end{array}$ \\
\hline
\end{tabular}

Taking advantage of previous studies

- Choosing the appropriate semi-experimental design for this study, which is based on my group.

- To contribute to the objective and scientific interpretation of the results of the current study.

- The preparation of study tools builds the test of compromise thinking.

- Identify many books and sources that enrich the current message.

- Selection of appropriate statistical means for current research procedures and results.

- Strengthening the problem and relevance of current research and demonstrating the need for it.

Research Actions

First, experimental design:

The experimental design represents the researcher's plan to carry out the experiment, i.e.: The plan against which individuals are allocated to experimental conditions, or experimental treatments are allocated to individuals in the research sample (Nederley, 2014: 158) The researcher has adopted the micro-tuned experimental design with two equivalent sets (a Rothkov Model Pilot and a Traditional Method Officer) of Tribal and Dimension Tests for the Development of Compromise Thinking.

Table (2): Experimental design

\begin{tabular}{|c|c|c|c|c|c|}
\hline Test & $\begin{array}{l}\text { Dependent } \\
\text { variable }\end{array}$ & $\begin{array}{l}\text { Independent } \\
\text { variable }\end{array}$ & Parity & & the group \\
\hline \multirow[t]{2}{*}{$\begin{array}{l}\text { The } \\
\text { Combinatorial } \\
\text { Reasoning Test }\end{array}$} & \multirow[t]{2}{*}{$\begin{array}{l}\text { Compromise } \\
\text { thinking }\end{array}$} & Rothkopf model & \multirow{2}{*}{\multicolumn{2}{|c|}{$\begin{array}{rr}\text { Age is calculated } & -1 \\
\text { in months. } & \\
\text { Intelligence } & -2 \\
\text { (Raven). } & \\
\text { Test driving } & -3 \\
\text { information. } & \\
\text { Synthesis } & -4\end{array}$}} & Experimental \\
\hline & & Traditional way & & & Control \\
\hline
\end{tabular}

Second: Research Community

All individuals (persons) around whom the research problem revolves are referred to as the research community and to whom the results of the research can be disseminated (Adnan, 2010: 101). In current research, the research community includes all fourth graders in the Samarra District (Preparatory and Secondary) Government Day Schools for Girls at Samarra District Centre for the academic year (2019 - 2020).

Third: Research Sample:

The current research requires choosing one of the secondary schools in the city of Samarra, provided that the number of the fourth literary class in it is not less than two divisions. One of the schools affiliated to the Salah alDin Education Directorate / Samarra District was chosen to conduct the experiment in it, and by the random withdrawal method the researcher chose my division ( A, B) by random drawing method, to form the two research groups, and in the same way the researcher chose Division (B) to represent the experimental group and the number of its students (38) students who will study their students according to

(Rothkopf model), Division (A) represented the control group and the number of its students (39) students whose students would be studied according to (the traditional method, Table 1) illustrates this. 
Table (3): Distribution of the research sample students to the experimental and control groups before and after excluding sediments

\begin{tabular}{|c|c|c|c|c|}
\hline $\begin{array}{c}\text { The number of } \\
\text { students after } \\
\text { exclusion }\end{array}$ & $\begin{array}{c}\text { Number of } \\
\text { deposits }\end{array}$ & $\begin{array}{c}\text { The number of } \\
\text { female students } \\
\text { before exclusion }\end{array}$ & Division & Group \\
\hline 38 & 1 & 39 & A & Control \\
\hline 36 & 2 & 38 & B & Experimental \\
\hline 74 & 3 & 77 & Total \\
\hline
\end{tabular}

Fourth: Equivalence of the two research groups: -

The researcher was keen, before starting the experiment, to statistically equal the requests of the two research groups in some of the variables that she believes may affect the safety of the experiment, and these variables are:

1- Age calculated in months 2. Intelligence (Raven). 3. Driving Information Test 4. Synthesis Thinking.

Fifth: Control of extraneous variables: -

Despite the development of educational and psychological sciences and their attempt to catch up with the natural sciences in the accuracy of procedures, and in the frequent use of experts in this field the experimental method, they are fully aware of the difficulties they face in isolating or controlling the variables of the phenomena that they study, because behavioral phenomena are non-physical and complex phenomena the factors overlap and intertwine

(Hammam, 1984, pp: 203-204) In addition to the aforementioned procedure of statistical equivalence between the two research groups in the four variables that affect the dependent variable, the researcher tried as much as possible to avoid the interference of some of the internal variables in the course of the experiment, because controlling them leads to results Accurate, and among these variables and how to adjust them: -

1- Experimental extinction: -

What is meant is the effect resulting from leaving a number of students (the research sample) and their interruption during the current experiment and research in which the requests were not subjected to abandonment or interruption, or the transfer from the school for the duration of the experiment. Except for the individual absences that the two research groups were subjected to, and they were often equal.

2- Differences in the test of individuals of the sample: The researcher tried as much as possible to avoid the effect of this variable by conducting statistical parity between students of the experimental and control research groups in four variables whose interference with the independent variable could have an effect on the dependent variable, in addition to the fact that students belong to a social environment and the economy is nearly the same.

3- Processes related to maturity: - It refers to the psychological and biological development processes that may occur to the individuals of the experiment during its conduct, which affects their responses (Al-Zobaie and others, 1981, 85) these processes had no effect in the current research, because the duration of the experiment was uniform for the two research groups.

4- Measurement tool: -

The researcher used a unified tool to measure the conciliatory thinking of the requests of the two research groups, as the researcher built the combinative thinking test for the purposes of the current research applied to the experimental and control research groups simultaneously.

5- The effect of the pretest: -

The researcher limited this factor by applying the combinative thinking test, due to the lack of a pre-test to measure reconciliatory thinking.

6- The effect of experimental procedures:

In order to protect the experiment from some measures that may affect the dependent variable, the researcher's work - as much as possible - to reduce the impact of this factor on the course of the experiment.

7- Duration of the experiment:

The duration of the experiment was uniform and equal for the students of the experimental and control groups, as it began on Wednesday 10/24/2019 and ended on Tuesday 14/1/2020 AD.

Fifth: Research requirements: -

The current research requires the following:

1- Identification of scientific material:

The scholar has identified the subject that he will study for female students of the two research groups in the course of the experiment, which are the subjects from the history course book to be taught to students of the literary class for the 2019/2020 academic year.

2- Formulation of behavioral objectives:

The setting of behavioral goals is essential in the educational process. It allows the evaluation of the adequacy and effectiveness of teaching in a specific and clear way, and is easy to measure because it illustrates teaching goals in observable and measurable terms. 1972. p:72)

3- Preparation of educational plans:

Teaching plans are defined as "the brevity that gives to the commentary of everything to be accomplished in class, and the particular means that are used for this purpose as a result of the events occurring during the presentation of the course of study (Delime, 2004, 271)." 
4- Search tool: -

A- Content Analysis Tool: -

The content analysis method is intended as a method of research to describe the apparent content of communication in an objective and quantitative manner (Jaber and Kathem, 1973, 160).

The researcher built the content analysis tool according to the following steps:

B- Preparing the list of conciliatory thinking: -

The researcher decided to prepare conciliatory thinking, with the intention of building a test for it, so the researcher took the following actions:

1- Interviewing with a number of specialists in methods of teaching history, measurement and evaluation, and Arab-Islamic history teachers, and trading with them

2- Reviewing some literature and previous studies that talked about compromise thinking

Then, the questionnaire was presented in its initial form to (14) specialists in educational and psychological sciences, methods of teaching history, and history teachers, and they were asked to read the test of combinational thinking contained in the questionnaire and express their opinion on the following aspects:

1- This test belongs to combinational thinking.

2- The accuracy of the paragraphs and the clarity of their meaning.

3- Deleting paragraphs that are not related to compromise thinking.

C- Analysis sample: -

The educational content was chosen from the history textbook to be taught for the fourth literary grade for the year (2019 AD / 2020 AD), which consists of five topics

The following is a clarification of the statistical analysis procedures for the test items: -

1- Difficulty level:

The researcher calculated the degree of difficulty of each essay paragraph by calculating the total scores of the students of the two groups, the upper group and the lower group on the paragraph, using the difficulty factor, and the researcher found that it falls between $(0,36-0,56)$ and thus the essay test items are considered good with regard to female students

2-Discrimination power:

The researcher calculated the discriminatory strength for each paragraph by calculating the total scores of the upper group's requests on the paragraph and the total scores of the lower group's students on the same paragraph, and by using the discriminatory strength factor for the essay test items, it was found that it falls between (0.330.47) and thus the test items are counted Good and of suitable discriminating power.

Fifth: Application of the experiment:

The experiment was launched on Wednesday, 24 October 2019, and ended on Tuesday, 14 October 2020, with two classes per group per week.

1- He studied the pilot and control research groups himself in accordance with his teaching plans.

2- The Compromise Thinking Test was applied to the requests of the pilot and control research groups simultaneously on Thursday, 16/1/20120, at 8.30 for the purpose of measuring the Compromise Thinking Test.

Sixth: Statistical means:

In its research and analysis procedures, the researcher used the following statistical means:

$\mathrm{T}$ test for two independent samples:

The researcher used the T-test to verify the parity of the two experimental and control groups in some variables and to calculate the semantics of their differences in the compromise test:

Chi-Square:

The researcher was used to determine the degree of compatibility between experts in the validity of the compromise thinking test and to determine the significance of differences between the two sets of research at statistical parity in parents' learning achievement variables.

The difficulty equation of the paragraph:

The researcher was used to calculate the difficulty of each paragraph of the compromise test.

Equivalence of the paragraph distinction factor:

The researcher used to calculate the power of differentiation in each paragraph of the Compromise Thinking Test.

Pearson Association Factor:

Use to calculate the stability coefficient of the compromise thinking test.

T-test for two linked samples:

Used for testing first and second search hypotheses.

Presentation and interpretation of results

The results for the first zero hypothesis do not make a statistically significant difference at the level of significance (05.0) between the average score of female students of the experimental group studying history at Rothkopf and the average score of female students of the officer group studying the same subject in the traditional way of a compromise thinking test.

To verify this hypothesis, the researcher calculated the arithmetic mean and the TVR using the TVR test. (ttest) Two independent samples to compare the average score of female students of the experimental group with the average score of female students of the consenting group, the arithmetic average of female students of the experimental group was (36.45) with a standard deviation of (78.7), while the arithmetic average of female 
students of the controlling group (07.40) with a standard deviation of (84.8) and the calculated TVR and (72.2), which is greater than the table value of 2 at the degree of freedom (72) and the level of significance (0.05).

This shows that there is a statistically significant difference between the middle grades of female students of the two research groups (pilot and officer) in the Compromise Thinking Test and in the interest of the Experimental Group. This result shows that female students of the pilot group who studied at the Rothkov Model are superior to female students of the officer group who studied according to the traditional method of the Compromise Thinking Test and a table (2) showing this.

Table (2) Results of the TVT test for the scores of female students of the two research groups in the TVT test

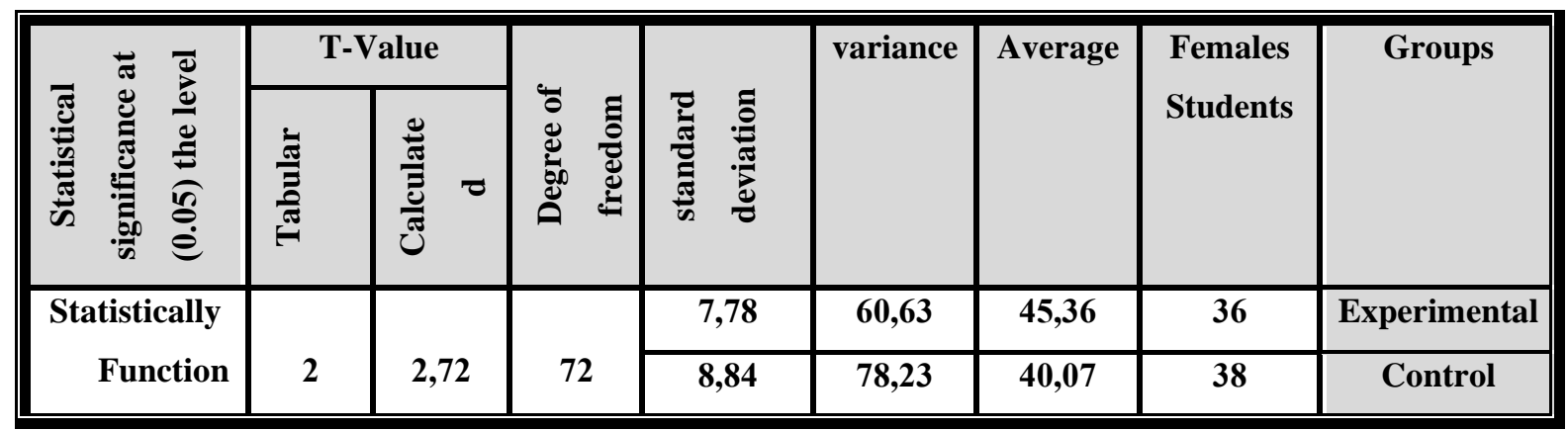

The results of the second null hypothesis There is no statistically significant difference at the level of significance $(05,0)$ between the average differences in the scores of the pre and post tests for the experimental group students who are studying history according to the Rothkopf model and the average differences in the scores of the pre and post tests for the students of the control group Those who study the same subject according to the traditional method of testing the development of compromise thinking

The researcher used the T-test of two linked samples to determine the significance of the differences between the tribal and the remote tests of both the experimental and control research groups to judge development in compromise thinking through the data shown in table (3). The average arithmetic value of the differences between the tribal and dimension tests of the experimental group's compromise thinking test was (77.10), with a standard deviation of (82.11), and the computed tip value of two related specimens was (47.5), and compared with the very tabular tip value (04.2) at the semantic level $(05,0)$ and degree of freedom (35).

We find that the calculated value is higher than the tabular value, which shows that the difference is statistically significant and that this difference in compromise thinking is in favors of the experimental group, i.e., there is a development in compromise thinking in female students of the pilot group after the experiment and the introduction of the independent variable model (Rothkopf). $t$ also appears in Table (3) that the arithmetic means of the differences between the pre and tests for the conciliatory thinking test for the control group, which is (26.4), with a standard deviation of (31.14) and the T value calculated for two correlated samples of (83.1), and by comparing it with the value the tabular $\mathrm{T}$ of $(04,2)$ at the level of significance $(05.0)$ and the degree of freedom (37).

We find that the calculated $\mathrm{T}$ value is smaller than the tabular value, and although the arithmetic mean of the post test is greater than the arithmetic mean of the pre-test, but the value of the difference is not statistically significant, and this means that there is no development of compromise thinking among the students of the control group. Table (3) illustrates

Table (3) the results of (t-test) for two correlated samples to clarify the differences between the pre- and posttests on the combinative thinking test for the experimental and control groups

\begin{tabular}{|c|c|c|c|c|c|c|c|c|c|}
\hline \multicolumn{3}{|c|}{\begin{tabular}{|lr} 
T-value and $\begin{array}{r}\text { statistical } \\
\text { significance }\end{array}$ \\
\end{tabular}} & \multirow{2}{*}{ 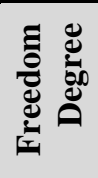 } & \multirow[t]{2}{*}{$\begin{array}{l}\text { Standard } \\
\text { Diviation }\end{array}$} & \multirow{2}{*}{ 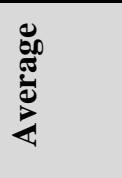 } & \multirow[t]{2}{*}{ Mean } & \multirow[t]{2}{*}{ Test } & \multirow[t]{2}{*}{ Size } & \multirow[t]{2}{*}{ Groups } \\
\hline $\begin{array}{r}\text { indicat } \\
\text { ion }\end{array}$ & Table & Count & & & & & & & \\
\hline \multirow{2}{*}{$\begin{array}{c}\text { Functi } \\
\text { on }\end{array}$} & \multirow[t]{2}{*}{2,04} & \multirow[t]{2}{*}{5,47} & \multirow[t]{2}{*}{35} & \multirow[t]{2}{*}{11,82} & \multirow[t]{2}{*}{10,77} & 104,19 & Before & \multirow[t]{2}{*}{36} & \multirow{2}{*}{$\begin{array}{r}\text { Experime } \\
\text { ntal }\end{array}$} \\
\hline & & & & & & 114,97 & After & & \\
\hline \multirow{2}{*}{$\begin{array}{c}\text { Non } \\
\text { Functi } \\
\text { on } \\
\end{array}$} & \multirow[t]{2}{*}{2,04} & \multirow[t]{2}{*}{1,83} & \multirow[t]{2}{*}{37} & \multirow[t]{2}{*}{14,31} & \multirow[t]{2}{*}{4,26} & 101,39 & Before & \multirow[t]{2}{*}{38} & \multirow[t]{2}{*}{ Control } \\
\hline & & & & & & 105,65 & After & & \\
\hline
\end{tabular}

Discussing and interpreting related findings:

- the Rothkopf model leads to a logical sequence of ideas, facts and information contained in the educational material, and then the use of this model led to an increase in the adaptive thinking of the students.

- the Rothkopf model increases the student's level of cognitive structures, as Piaget affirms that the emergence of students 'cognitive structures and inferential processes are consistent with the foundations of combinational thinking. Therefore, the use of this model led to an increase in the students' logical thinking.

- teaching according to the Rothkopf model leads to an increase in the students 'effectiveness of learning, as the information is given to the students in a logical and psychological sequence of the ideas, facts and information 
contained in the educational material, as well as the questions selected from the texts contain a higher mental pattern and lead to better learning.

The Rothkopf model provided the students with the opportunity to ask scientific questions and inquiries related to the subject of biology and to arouse their enthusiasm to find answers to these questions and then understand and comprehend these situations, which helped in the development of their conciliatory thinking.

\section{Conclusions:}

Based on the results of the current research, the following conclusions were reached:

1 - Teaching according to the Rothkopf model contributed to the existence of statistically significant differences in favor of the experimental group at the expense of the control group

2- Teaching according to the Rothkopf model raised the level of conciliatory thinking for fourth-grade literary students by making them the focus of the educational process and greatly enhancing the knowledge structures that they have.

\section{References}

1. Abd Nour, Kazem (2005): Studies and Research in Psychology, Education of Thinking and Creativity, 1st Edition, Debono Publishing and Distribution House, Amman-Jordan.

2. Abdul Hadi, Nabil, (2004): Contemporary Educational Models, 1st Edition, Wael House, Amman.

3. Abdul-Rahman, Dhay Auf (2018), "Conciliatory thinking and its relationship to the influential personality of university students", (unpublished master's thesis), College of Education for Human Sciences University of Diyala, Iraq.

4. Abdul-Rahman, Dhay Auf (2018), "Conciliatory Thinking and Its Relation to the Influential Personality of University Students", (Unpublished Master Thesis), College of Education for Human Sciences University of Diyala, Iraq

5. Al-Alusi, Akram Taha Yassin (2002) The Effect of Using Historical Maps and Time Pictorials on First Intermediate Students' Achievement in History, Unpublished Master Thesis, College of Education / University of Baghdad, Iraq

6. Al-Amin, Shaker Mahmoud and others (1992): Fundamentals of Teaching Social Subjects, 1st Edition, Dar Al-Hikma Printing Press, Baghdad

7. Al-Bayati, Abdul-Jabbar, Tawfiq, and Zakaria Asasios. (1977): Inferential Statistics in Education and Psychology, Workers Culture Foundation Press, Baghdad

8. Al-Mufleh, Abdullah bin Muhammad (2008): Flexible Thinking Skills Course Sixteenth Teaching Program, Charitable Project Hall of Saud Al-Basatin Charitable Center for Heritage and Culture, Riyadh, Saudi Arabia

9. Al-Obeidi, Awatif Muhammad Hamid (2006), The Impact of Teaching Using Historical Maps and Timepieces on Achievement and Retention of Second Intermediate Students in History, Higher Arab Institute for Educational and Psychological Studies, Unpublished Master Thesis, Baghdad, Iraq.

10. Al-Obeidi, Muhammad Jasim, (2004). Individualization of Education and Continuing Education, 1st Edition, House of Culture for Publishing and Distribution, Amman

11. Al-Obeidi, Muhammad Jasim, (2004). Unique Education and Continuing Education, 1st Edition, House of Culture for Publishing and Distribution, Amman.

12. Al-Sudani, Wafaa Mohsen Mashhouat (2007): Asher method of group discussion in the acquisition and retention of historical concepts among second-grade intermediate students, (unpublished master's thesis), College of Education - Ibn Rushd, University of Baghdad 0

13. Al-Zaghoul, Imad, (2003): Theories of Learning, Dar Al-Shorouk Publishing and Printing, Amman.

14. Al-Zaghoul, Imad, (2012): Principles of Psychology, University Book House, Al-Ain.

15. Al-Zobaie, Abdul-Jalil Ibrahim, and others. (1981): Psychometric Tests, Ministry of Higher Education and Scientific Research, Dar Al-Kutub for Printing and Publishing, University of Mosul.

16. Edward, Debono (2010): Teaching Six Hats Thinking, Teachers' Guide, Dar Al-Masirah, Amman

17. Hamid, Salma Majeed (2006), The Impact of an Educational Strategy by Simultaneous Drawing and Explanation on Achievement, Motivation, and the Development of the Skill of Historical Cartography among Middle School Students, Unpublished PhD thesis, Al-Mustansiriya University, College of Education, Iraq.

18. Idris, Abbas (2010): Analytical thinking and its relationship to opposing ideas and the Farsi style, (unpublished PhD thesis), College of Arts - University of Baghdad, Iraq.

19. Mari, Tawfiq Ahmed, and Muhammad Mahmoud Al-Haila, (2009): General Teaching Methods, 4th Edition, Dar Al-Masirah, Amman. 
20. Melhem, Sami, (2001): The Psychology of Learning and Teaching, 1st Edition, Dar Al Masirah for Publishing and Distribution, Amman.

21. Muhammad, Aamal Jumaa Abdel Fattah (2015): Thinking Skills: A Contemporary Educational Vision, 1st Edition, University Book House for Publishing and Distribution, Lebanon, United Arab Emirates

22. Obaid, William, (2009): Teaching and Learning Strategies, 1st Edition, Dar Al Masirah, Amman.

23. Qutami, Yusuf, (2013): The Epistemological Theory in Learning, Dar Al-Masirah, Amman.

24. Saadeh, Jawdat Ahmad (2006): Teaching Thinking Skills, Dar Al Shorouk for Publishing and Distribution, Amman, Jordan.

25. Sabry, Maher, (2002): The Arab Encyclopedia of Education Terminology and Educational Technology, 1st Edition, Al-Rashed Library, Riyadh.

26. Shehata, Hassan (2003): Educational perspectives towards the development of learning in the Arab world between reality and the future, 1st Edition, Egyptian Lebanese Publishing House.

27. Shehata, Hassan (2009): Curriculum Design and Progress Values in the Arab World, 2nd Edition, Cairo, The Egyptian Lebanese House 